\title{
ANTHROPOMETRY OF THE EXTERNAL EAR AMONG ADULT IJAWS IN BAYELSA STATE OF NIGERIA
}

\author{
E.I. Edibamode1, K. Mordi', L.K. David', A.M. Eghoi' \\ 1 - UNIVERSITY OF PORT HARCOURT, PORT HARCOURT, NIGERIA \\ 2 - ABIA STATE UNIVERSITY, UTURU, NIGERIA
}

Background. External ear measurement is of utmost importance in reconstructive surgeries.

Objectives. The present study is aimed at ascertaining sexual dimorphism in external ear anthropometry and ear lobe attachments among adults Ijaws in Bayelsa, Nigeria.

Methods. A total of 112 adults within the age range of 18-50yrs, who met the inclusion criteria, were involved in the study. Four linear dimensions of the ear, which are ear length (EL), ear width (EW), lobular length (LL) and lobular width (LW), were measured for both genders. The lobular attachment for both ears for males and females were also examined and results recorded. These data were subjected to Student t-test, Chi-square test, and Pearson's correlation using SPSS version 20.0.

Results. The mean values for $E L, E W, L L$, and $L W$ for the left auricle in the males and females were 58.14 \pm 0.60 , $27.41 \pm 0.37,14.47 \pm 0.27,13.50 \pm 0.34$ and $57.90 \pm 0.16,27.45 \pm 0.65,15.41 \pm 0.31,13.43 \pm 0.38$ respectively. However, for the right auricle in the males and females, the values were 58.40 $\pm 0.45,28.21 \pm 0.68,14.32 \pm 0.31,13.04 \pm 0.32$, and $56.66 \pm 1.10,27.51 \pm 0.65,15.58 \pm 0.29,13.28 \pm 0.34$ respectively. The left and right lobular length were the only parameters that proved statistical significance $(p<0.05)$ in females compare to males. Pearson's correlations between right and left sides for each of the parameters were positive and significant. Chi-square analysis revealed no significant relationship ( $p>0.05$ ) between earlobe attachments and gender.

Conclusions. Sexual dimorphism was thus established in the Ijaw population as regards lobular length dimensions. It is believed that the results of this study would be very useful for ear morphology and reconstructive surgeries.

KEY WORDS: external ear (auricle); Bayelsa Ijaws; anthropometry; sexual dimorphism; lobular attachment.

\section{Introduction}

Anthropometry refers to the branch of anthropology concerned with comparative measurements of the human body for the purpose of understanding of physical variations in humans [1]. These body measurements have been shown to vary according to sex, age and race, thus the study of these physical variations is of utmost importance in plastic surgery, prosthetics, clothing designs, and ergonomics [2-3]. It is also important for development of personal individuality [2].

The human external ear is an important organ contributing to the esthetics of human face. Its size, shape, position, and projection influence the facial appearance of the individual [4]. It consists of external, middle and internal parts. The external ear is made up of a shell-like auricle (pinna), which collects sound, and the

Corresponding author: Azibaediya M. Eghoi, M.Sc.,Department of Human Anatomy, Faculty of Basic Medical Sciences, Abia State University, Uturu, Abia State, Nigeria e-mailazibsmil32@yahoo.com external acoustic meatus, which conducts sound from the pinna to the tympanic membrane [5]. The auricle, helical in shape, is made up of an elastic cartilage covered by skin and has several depressions and elevations. The lobule (earlobe) of the auricle is a tag of skin containing fibrofatty tissue and blood vessels and is easily pierced for taking blood samples and inserting earrings $[5,6]$. It is the last part of the auricle to develop [7]. Earlobe attachments were mainly classified into attached and free (unattached) earlobes [8-12]. Many authors, however, have pointed out that there are many people with intermediate (or tapering) earlobes [13-14]. Individuals having earlobes that hang freely are known to have free (unattached) earlobes, whereas those having earlobes fused with the sides of proximal head are termed as attached (or adherent) earlobes [15-16].

Several anthropometric studies on ear measurements have been carried out on different populations. According to the studies 
carried out in India and Urhobo people of Southern Nigeria, females were found to have a statistically higher lobular length and width compare to males $[3,17]$. The studies in American, Italian, Indian, Israeli and Turkish populations suggested that boys and men had larger ears than girls and women [8, 19-26]. Similar studies have shown that auricular dimensions in northern Nigeria are higher in males compare to females [27]. The reports by Sharma [3], however, documented that ear dimensions were higher in males than females $[3,17]$. The studies by Wang, et al [18] of a Chinese population, however suggested that lobular dimensions were not significantly different in both genders.

Despite a large number of world publications on the anthropometric measurement of the external ear, the studies correlating the dimensions of the external ear and sexual dimorphism in adult Nigerian population show paucity of information. Thus, the purpose of this study is to determine sexual dimorphism in mean ear dimensions and earlobe attachments among adult Ijaws in Bayelsa State of Nigeria.

Previous studies on the morphometric analysis of the external ear have been carried out previously in several countries including Nigeria, however, the studies correlating the dimensions of the external ear and sexual dimorphism in adult Bayelsa Ijaws show paucity of information and have necessitated the need for this study. Hence the present study aims to ascertain the anthropometry of the external ear among adults Ijaws in Bayelsa state of Nigeria.

The objectives of this study are:

To determine the mean dimensions of ear length (EL), ear width (EW), lobular length (LL) and lobular width (LW) among Bayelsa Ijaws.

To ascertain if there may exist a sexual dimorphism among the parameters mentioned above.

To ascertain if there is any correlation in the measured parameters of the external ear in sexual dimorphism.

To determine the variation in attachment of earlobe among Ijaws.

\section{Methods}

The study involved the subjects from various local governments in Bayelsa state: Yenagoa, Sagbama, Southern Ijaw, Nembe, Kolokuma, Ekeremor and Ogbia local government area. The study was conducted on adult Ijaws, whose parents were indigenes of
Bayelsa state in Nigeria up to their second generation. The sampling method used for the selection of subjects was a simple random sampling method. A total of 112 subjects were involved: 59 males and 53 females. Only the subjects within the age range of 18-50 years of the Ijaw ethnic group in Bayelsa state without anomalies to their external ears comprised this study. The subjects with ear defects and those with previous history of ear surgery were excluded from the study. Also the subjects, who had not given their consent, were also excluded from the study.

The procedure for ear measurements was explained to the subject in order to get maximum cooperation. With the subject's head in Frankfort horizontal plane, direct measurements were taken using a digital vernier caliper with resolution of $0.01 \mathrm{~mm}$ as follows [3]. The anthropometric parameters of the external ear measured were (Fig. 1):

Total length of ear (TLE) - measured as the distance between the superior projection of the helix and inferior projection of the external ear $(A B)$.

Total width of ear (TWE) - measured as the distance between the anterior and superior points of the external ear (CD).

Total lobular width (TLL) - measured from the midpoint of the intertragic notch to the lowest point of the lobule (GB).

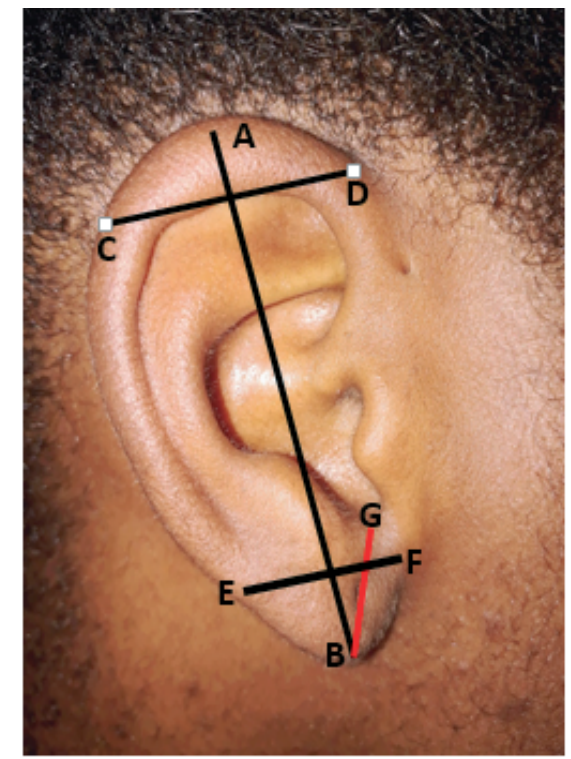

Fig.1. Photograph of the lateral surface of the auricle displaying the measured parameters.

Notes: $A B$ - total length of ear;

$C D$ - total width of ear;

BG - total lobular length;

EF - total lobular width. 
Total lobular width (TLW) - measured as the transverse distance of the ear lobule passing through the center of the length of the lobule (EF).

Data analysis was performed using Statistical Package for Social Sciences (SPSS) version 20.0 with results expressed as mean and standard error of mean (Mean \pm SE). The Student independent sample t-test with a twotail distribution was applied to compare the ear measurements between males and females in the study population. P-values, less than 0.05 $(p<0.05)$ were considered to be significant. Chisquare test was used to determine the relationship between gender and left lobular attachment of the population. Pearson's correlation coefficient test was conducted to determine the symmetry between the right and left side ear measurements of each gender and for the study population.

Correlation coefficient ( $r$ value) was interpreted as follows:
a. <0.2 - a slight correlation
b. 0.2-0.4 - a weak correlation
c. 0.4-0.7 - a moderate correlation
d. 0.7-0.9 - a high correlation
e. $>0.9$ - an almost perfect correlation

\section{Results}

The distribution of the subjects involved in the study according to the various Local Government areas of Bayelsa State is presented in Table 1.

Table 1. Detailed analysis of the subjects according to gender and local government areas (LGA) in Bayelsa State.

\begin{tabular}{|c|l|c|c|}
\hline \multirow{2}{*}{ S/N } & \multirow{2}{*}{ LGA } & \multicolumn{2}{c|}{ Gender } \\
\cline { 3 - 4 } & & Female & Male \\
\hline 1 & Ekeremor & 11 & 6 \\
\hline 2 & Kolokuma & 4 & 6 \\
\hline 3 & Nembe & 9 & 2 \\
\hline 4 & Ogbia & 2 & 4 \\
\hline 5 & Sagbama & 15 & 11 \\
\hline 6 & Southern Ijaw & 8 & 17 \\
\hline 7 & Yenagoa TOTAL & 54 & 58 \\
\hline \multicolumn{2}{|l}{} \\
\hline
\end{tabular}

Seventeen of the subjects hailed from Ekeremor, 10 from Kolokuma, 11 from Nembe, 6 from Ogbia, 17 from Sagbama, 20 from Yenagoa, 27 from Southern Ijaw Local Government Area of Bayelsa State. The result prove that out of the total number of the subjects, who consented and participated in the study,

Table 2. General characteristics of the study population $(n=112)$

\begin{tabular}{|l|c|c|c|c|c|c|c|}
\hline Variables & Mean & SEM & SD & Range & Min & Max & Variance \\
\hline Age & 26.69 & 0.71 & 7.56 & 32.00 & 18.00 & 50.00 & 57.08 \\
\hline LEL & 58.02 & 0.38 & 4.02 & 30.34 & 39.77 & 70.11 & 16.12 \\
\hline LEW & 27.43 & 0.36 & 3.86 & 36.33 & 19.97 & 56.30 & 14.91 \\
\hline LLL & 14.93 & 0.21 & 2.18 & 11.12 & 9.12 & 20.24 & 4.76 \\
\hline LLW & 13.47 & 0.25 & 2.69 & 16.85 & 4.40 & 21.25 & 7.24 \\
\hline REL & 57.56 & 0.58 & 6.16 & 53.20 & 16.20 & 69.40 & 37.96 \\
\hline REW & 27.87 & 0.47 & 4.98 & 39.78 & 19.98 & 59.76 & 24.77 \\
\hline RLL & 14.92 & 0.22 & 2.34 & 13.28 & 9.56 & 22.84 & 5.47 \\
\hline RLW & 13.15 & 0.23 & 2.45 & 10.68 & 7.60 & 18.28 & 6.02 \\
\hline
\end{tabular}

Notes: REL - right ear length; LEL - left ear length; REW - right ear width; LEW - left ear width; RLL - right lobular length; LLL - left lobular length; RLW - right lobular width; LLW - left lobular width; SEM - standard error of mean; SD - standard deviation.

Table 3. Comparison of the measurements of the study population ( $n=112)$.

\begin{tabular}{|l|c|c|c|c|}
\hline \multicolumn{1}{|c|}{ Variable } & $\mathbf{n}$ & $\mathbf{T}$ & $\mathbf{P}$ & Inference \\
\hline Left ear length-right ear length & 112 & 0.788 & 0.433 & NS \\
\hline Left ear width-Right ear width & 112 & -0.813 & 0.418 & NS \\
\hline Left lobular length-right lobular length & 112 & 0.004 & 0.997 & NS \\
\hline Left lobular width-right lobular width & 112 & 2.011 & 0.047 & NS \\
\hline
\end{tabular}

Notes: $\mathrm{P}$ - the statistical significance was determined using paired sample T-test; $\mathrm{P}<0.05$ - significance between mean values; $\mathrm{n}$ - sample size; NS - not significant; $\mathrm{S}$ - significant. 
54 are females and 58 - males (Table1). The mean values, standard deviation, standard error and variance for each variable of each ear measured in the study population $(n=112)$ are enlisted in Table 2 . The results also proved that values for the right ear measurements did not significantly differ $(p>0.05)$ from that on the left (tables 2 \& 3) for the study population.

The results of the population data subjected to Chi-square analysis at $95 \%$ and $99 \%$ confidence interval is presented in Table 4.

The results attained proved that there was a weak correlation ( $r=0.3$ ) in the left and right ear length of the study population $(n=112)$. The $P$ value for the correlations was found to be $<0.05(P=0.001)$, hence the correlation was statistically significant. Left and right ear width however showed a slight correlation, which was not significant $(P=0.073 ; r=0.2)$. Significant correlations were found in the study population between the right and left side of lobular length
$(P=0.000 ; r=0.7)$ and that of lobular width $(P=0.000 ; r=0.7)$.

In Tables 5, 6, and 7, four important indices (ear width, ear length, lobular length and lobular width) were assessed and compared in both and within the sexes. It was evidenced that females had a significantly larger dimensions $(p<0.05)$ of left lobular length and right lobular length compare to that of males (table 5).

The dimensions for left lobular length and right lobular length were $15.41 \pm 0.31$ and $15.58 \pm 0.29$ in females, whereas in males $14.47 \pm 0.27$ and $14.32 \pm 0.31$ respectively. Apart from the left and right lobular length that proved higher mean values in females, the mean values of other parameters were not consistently higher $(p>0.05)$ in one gender with respect to a side (Table 5). Within the male population, the right ear measurements did not significantly statistically differ $(p>0.05)$ from that on the left (Table 6).

Table 4. Pearson correlation of right and left side measurements of the study population ( $n=112)$.

\begin{tabular}{|l|c|c|c|c|}
\hline \multicolumn{1}{|c|}{ Variable } & $\mathbf{n}$ & $\mathbf{R}$ & $\mathbf{r}^{2}$ & $\mathbf{P}$ \\
\hline Left ear length-right ear length & 112 & 0.307 & 0.094 & 0.001 ** \\
\hline Left ear width-Right ear width & 112 & 0.170 & 0.029 & 0.073 \\
\hline Left lobular length-right lobular length & 112 & 0.654 & 0.428 & $0.000^{* *}$ \\
\hline Left lobular width-right lobular width & 112 & 0.799 & 0.638 & $0.000^{* *}$ \\
\hline
\end{tabular}

Notes: $\mathrm{n}$ - sample size; $\mathrm{r}$ - coefficient of correlation; $\mathrm{p}$ - statistical significance; superscript * - correlation at 0.05 level $(p<0.05) ; * *$ - correlation at 0.01 level $(p<0.01)$.

Table 5. Comparison of ear measurements between the male and female study population.

\begin{tabular}{|l|c|c|c|c|c|c|}
\hline \multicolumn{1}{|c|}{ Variable } & Sex & $\mathbf{n}$ & Mean \pm SE & T value & P value & Inference \\
\hline Left ear length & Male & 58 & $58.14 \pm 0.60$ & 0.318 & 0.751 & NS \\
\hline & Female & 54 & \multicolumn{2}{|c|}{$57.90 \pm 0.46$} & & \\
\hline Left ear width & Male & 58 & $27.41 \pm 0.37$ & -0.055 & 0.956 & NS \\
\hline & Female & 54 & \multicolumn{2}{|c|}{$27.45 \pm 0.65$} & & \\
\hline Left lobular length & Male & 58 & $14.47 \pm 0.27$ & -2.327 & 0.022 & S \\
\hline & Female & 54 & \multicolumn{2}{|c|}{$15.41 \pm 0.31$} & & \\
\hline Left lobular width & Male & 58 & $13.50 \pm 0.34$ & 0.125 & 0.901 & NS \\
\hline & Female & 54 & \multicolumn{2}{|c|}{$13.43 \pm 0.38$} & & \\
\hline Right ear length & Male & 58 & $58.40 \pm 0.45$ & 1.505 & 0.135 & NS \\
\hline & Female & 54 & \multicolumn{2}{|c|}{$56.66 \pm 1.10$} & & \\
\hline Right ear width & Male & 58 & $28.21 \pm 0.68$ & 0.747 & 0.457 & NS \\
\hline & Female & 54 & \multicolumn{2}{|c|}{$27.51 \pm 0.65$} & & S \\
\hline Right lobular length & Male & 58 & $14.32 \pm 0.31$ & -2.954 & 0.004 & \\
\hline & Female & 54 & \multicolumn{2}{|c|}{$15.58 \pm 0.29$} & & NS \\
\hline Right lobular width & Male & 58 & $13.04 \pm 0.32$ & -0.508 & 0.613 & \\
\hline & Female & 54 & \multicolumn{2}{|c|}{$13.28 \pm 0.34$} & & \\
\hline
\end{tabular}

Notes: values are presented as Mean $\pm \mathrm{SE} ; \mathrm{P}$ - statistical significance was determined using independent sample T-test; $\mathrm{P}<0.05$ - statistical significance between mean values; $\mathrm{SE}$ - standard error; $\mathrm{n}$ - sample size; NS - not significant; $S$ - significant. 
Table 6. Comparison of measurements in males $(n=58)$.

\begin{tabular}{|l|c|c|c|c|}
\hline \multicolumn{1}{|c|}{ Variable } & $\mathbf{n}$ & $\mathbf{T}$ & $\mathbf{P}$ & Inference \\
\hline Left ear length-right ear length & 58 & -0.443 & 0.660 & NS \\
\hline Left ear width-Right ear width & 58 & -1.180 & 0.243 & NS \\
\hline Left lobular length-right lobular length & 58 & 0.543 & 0.589 & NS \\
\hline Left lobular width-right lobular width & 58 & 1.920 & 0.060 & NS \\
\hline
\end{tabular}

Notes: $\mathrm{P}$ - statistical significance was determined using paired sample T-test; $\mathrm{P}<0.05$ - significance between mean values; $n$ - sample size; NS - not significant; $\mathrm{S}$ - significant.

Similarly, the right ear indices (right ear length, right ear width, right lobular length, right lobular width) did not statistically significantly differ $(p>0.05)$ from that of the left (left ear length, left ear width, left lobular length, left lobular width) in female population (Table 7).

Tables 8 and 9 present the relationship between the lobular attachments of the ear in males and females subjects of Ijaw ethnicity. The proportion of the male subjects, whose left lobular attachment is either attached, free (unattached) or intermediate, were $22(19.6 \%)$, $17(15.2 \%)$ and $19(17.0 \%)$ respectively (Table 8$)$.
For female subjects, the proportions were 27 (24.1\%), 8 (7.1\%) and $19(17.0 \%)$ respectively. Results proved no significant relationship between the left lobular attachment and gender $\left(X^{2}=3.612 ; P=0.164\right)$. The proportion of the male subjects, whose right lobular attachment is either attached, free or intermediate, were $21(18.8 \%), 11(9.8 \%)$, and $26(23.2 \%)$ respectively (Table 9 ). On the other hand, the proportion of the female subjects, whose right lobular attachment was either attached, free or intermediate, were 14 (12.5\%), 6 (5.4\%), and 34 (30.4\%) respectively. There was no significant

Table 7. Comparison of the left and right ear measurements in females $(n=54)$.

\begin{tabular}{|l|c|c|c|c|}
\hline \multicolumn{1}{|c|}{ Variable } & N & T & P & Inference \\
\hline Left ear length-right ear length & 54 & 1.189 & 0.240 & NS \\
\hline Left ear width-Right ear width & 54 & -0.660 & 0.948 & NS \\
\hline Left lobular length-right lobular length & 54 & -0.813 & 0.420 & NS \\
\hline Left lobular width-right lobular width & 54 & 0.800 & 0.427 & NS \\
\hline
\end{tabular}

Notes: $\mathrm{P}$ - statistical significance was determined using paired sample T-test; $\mathrm{P}<0.05$ - statistical significance between mean values; $\mathrm{n}$ - sample size; NS - not significant; $\mathrm{S}$ - significant.

Table 8. Relationship between gender (sex) and left lobular attachment of the population ( $n=112)$.

\begin{tabular}{|l|c|c|c|c|c|c|c|}
\hline \multirow{2}{*}{ Sex } & \multicolumn{3}{|c|}{ Left lobular attachment } & \multirow{2}{*}{ Total } & \multicolumn{3}{c|}{ Chi-square analysis } \\
\cline { 2 - 4 } \cline { 6 - 8 } & Attached & Free & Intermediate & & df & $\mathbf{X}^{2}$ & p-value \\
\hline Male & $22(19.6 \%)$ & $17(15.2 \%)$ & $19(17.0 \%)$ & $58(51.8 \%)$ & 2 & 3.612 & 0.164 \\
\hline Female & $27(24.1 \%)$ & $8(7.1 \%)$ & $19(17.0 \%)$ & $54(48.2 \%)$ & & & \\
\hline Total & $49(43.8 \%)$ & $25(22.3 \%)$ & $38(33.9 \%)$ & $112(100.0 \%)$ & & & \\
\hline
\end{tabular}

Notes: the values are presented as frequencies and percentages; $\mathrm{P}<0.05$ - the association (or relationship) between variables.

Table 9. Relationship between gender (sex) and right lobular attachment of the population $(n=112)$.

\begin{tabular}{|l|c|c|c|c|c|c|c|}
\hline \multirow{2}{*}{ Sex } & \multicolumn{3}{|c|}{ Left lobular attachment } & \multirow{2}{*}{ Total } & \multicolumn{3}{c|}{ Chi-square analysis } \\
\cline { 2 - 4 } \cline { 6 - 8 } & Attached & Free & Intermediate & & df & $\mathbf{X}^{2}$ & p-value \\
\hline Male & $21(18.8 \%)$ & $11(9.8 \%)$ & $26(23.2 \%)$ & $58(51.8 \%)$ & 2 & 3.799 & 0.150 \\
\hline Female & $14(12.5 \%)$ & $6(5.4 \%)$ & $34(30.4 \%)$ & $54(48.2 \%)$ & & & \\
\hline Total & $35(31.3 \%)$ & $17(15.2 \%)$ & $60(53.6 \%)$ & $112(100.0 \%)$ & & & \\
\hline
\end{tabular}

Notes: the values are presented as frequencies and percentages. $\mathrm{P}<0.05$ means there is an association (or relationship) between variables. 
relationship between gender and right lobular attachments $\left(X^{2}=3.799 ; P=0.150\right)$.

\section{Discussion}

The current study presents anthropometric data regarding the external ear measurements for individuals of Bayelsa State, Nigeria. Gender (sexual) dimorphism was presented in the study as regards the measurement of lobular length. The results revealed that lobular length (left and right) were significantly higher $(p<0.05)$ in female subjects compared to that in males. These findings are supported by other studies carried out involving India and Urhobo people of Southern Nigeria, where females were also found to have a statistically higher lobular length than males $[3,17]$. Our findings however contradict with reports in northern Nigeria which showed that lobular dimensions were higher in males compare to females [27]. When the mean value for lobular length, measured on both sides with respect to gender, of our study was compared with other anthropometric studies in Nigeria, it was evidenced that Urhobo people of Southern Nigeria had similar mean values, while the residents of Maiduguri in Northern Nigeria had lower values. This implies that within Nigeria, people of different ethnicity and geopolitical zones have different dimensions of Lobular length. The findings by Wang et al. [18], in a Chinese population, however suggested that lobular dimensions were not significantly different in the two genders. The disparity in mean ear dimensions, across subjects in Nigeria as well as other countries of the world, could be attributed to differences in social and ethnic background.

The data of the present study was analyzed using Pearson correlation and it was observed that all parameters on both sides of the ear proved to have a positive linear relationship, which was highly significant $(P<0.05)$. This was similar to the findings of Ekanem et al. [4] and Eboh [17].

Analyzing the data with regards to sex of the subjects, it was observed that ear length and width did not vary significantly $(p>0.05)$ between males and females. Our findings however contradict with the reports in northern Nigeria, which showed that auricular dimensions were higher in males compare to females [4]. Similarly, our findings also contradicts with reports of Azaria et al. [8], Sharma et al. [9], Brucker et al. [19], Bozkir et al. [22] Purkait and Singh [27], Ito et al. [28], and Meijerman et al.
[29], who suggested that males have longer ears compare to females. The disparity in mean ear dimensions across the subjects in different countries of the world could be associated with difference in social and ethnic background.

Various authors have studied the attachment of ear lobules in different populations and its significance in population genetics $[11,15]$. The results of the present study, from data analyzed using Chi-square test, revealed no association ( $p>0.05$ ) between gender and lobular attachment for both ears. The frequency of attached, free and intermediate ear lobule in Ijaw population of Bayelsa State, Nigeria, were $43.8 \%, 22.3 \%$ and $33.9 \%$ respectively for the left ear and $31.3 \%, 15.2 \%$ and $53.6 \%$ respectively for the right ear. In other words, attached and intermediate ear lobules were found to be the predominant $(p>0.05)$ type of ear lobule in the Ijaw population of Bayelsa State, Nigeria. Our study corroborates with findings by Munir et al. [15], Shah et al. [30], Kim et al. [31], who revealed a higher frequency of attached and intermediate ear lobules in Japanese/Chinese and Indian population respectively. In a similar research carried out by Munier et al. [15], it was proved that no association ( $p>0.05$ ) existed between ear lobular attachment and gender. The present study however differs from the findings by Nwaopara et al. [32] and Singh and Sengupta [33], who have reported a higher frequency for free (unattached) ear lobule (63.4\%) amongst the population of Ekpoma, Nigeria and Assamese, India respectively.

\section{Conclusions}

The present anthropometric study on ear measurements revealed a significantly higher lobular length in females compare to males, thus sexual dimorphism was established as regards the measurement of lobular length in Ijaws population. Other parameters such as ear length, ear width, lobular width, and lobular attachment did not exhibit significant gender differences in the study population. There was a high correlation in the dimensions of ear length, lobular length, and lobular width of the pinna between the right and left sides in the study population. It is believed that the results of this study would be very useful in ear morphology and reconstructive surgeries.

\section{Acknowledgements}

Authors are thankful to the management and staff of BMH for assisting them at different stages of the study. Special thanks to the entire 
members of staff of the Department of Anatomy for their technical input and assistance.

\section{Conflict of interest}

The authors declare no conflict of interest.

\title{
АНТРОПОМЕТРИЧНІ ДОСЛІДЖЕННЯ ЗОВНІШНЬОГО ВУХА СЕРЕД ДОРОСЛОГО НАСЕЛЕННЯ ІДЖО ШТАТУ БАЙЕЛСА У НІГЕРІЇ
}

\author{
E.I. Edibamode' ${ }^{1}$, K. Mordi', L.K. David' ${ }^{1}$, A.M. Eghoi ${ }^{2}$ \\ 1 - UNIVERSITY OF PORT HARCOURT, PORT HARCOURT, NIGERIA \\ 2 - ABIA STATE UNIVERSITY, UTURU, NIGERIA
}

Вступ. Вимірювання зовнішнього вуха є надзвичайно важливим у морфології вуха та реконструктивній хірургії.

Мета роботи - дослідити статевий диморфізм у антропометрії зовнішнього вуха (довжина вуха, ширина вуха, висота вушної сережки (мочки), ширина мочки) та прикріплення мочки серед дорослого населення етнічної групи іджо у штаті Байелса, Нігерія.

Методи. Обстежено 112 дорослих віком від 18 до 50 років, які відповідали критеріям дослідження. Чотири лінійних виміри зовнішнього вуха, а саме довжина вуха (ДВ), ширина вуха (ШВ), довжина мочки (ДМ) та ширина мочки (ШМ) були проведені у досліджуваних осіб обох статей. Прикріплення мочки у чоловіків та жінок також фіксувалося. Отримані дані обробляли з використанням t-критерію Стьюдента, критерію Хі-квадрата корелячії Пірсона за допомогою програмного забезпечення SPSS версії 20.0.

Результати. Середні величини для досліджуваних показників ДВ, ШВ, ДМ,ШМ склали у чоловіків та

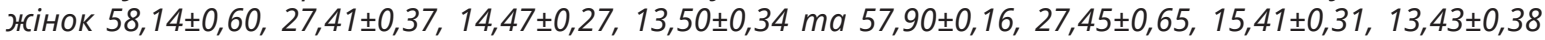

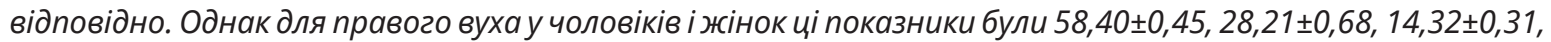

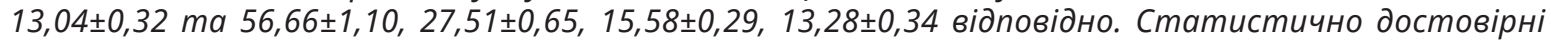
відмінності у розмірах були лише у показника довжини лівої і правої мочки у жінок відносно до чоловіків (р<0.05). Коефіцієнт кореляції Пірсона між параметрами правого та лівого вуха був достовірним та позитивним. За критерієм Хі-квадрата не було знайдено достовірних взаємозв'язків (p>0.05) у прикріпленні мочки вуха у різних статей.

Висновки. Проведене нами дослідження дозволило встановити статеві відмінності у довжині мочки вуха у популячії Ідж. Ці дані будуть корисними при вивченні морфології вуха та при проведенні реконструктивних втручань на вусі.

КЛЮЧОВІ СЛОВА: зовнішнє вухо(auricla); Іджо штату Байелс; антропометрія; статевий диморфізм; прикріплення мочки вуха.

\section{Information about authors}

Ezon-Ebidor I. Edibamode - PhD, Department of Human Anatomy, Faculty of Basic Medical Sciences, University of Port Harcourt, Choba,Port Harcourt, Rivers State, Nigeria.

e-mail: innocent.edibamode@uniport.edu.ng

Kurotimi Mordi - B.Sc, Department of Human Anatomy, Faculty of Basic Medical Sciences,

University of Port Harcourt, Choba, Port Harcourt, Rivers State, Nigeria.

e-mail: morditimi@gmail.com

Lekpa K. David - PhD, Department of Human Anatomy, Faculty of Basic Medical Sciences,

University of Port Harcourt, Choba, Port Harcourt, Rivers State, Nigeria.

e-mail: lekpa.david@uniport.edu.ng

Azibaediya M. Eghoi - M.Sc, Department of Human Anatomy, Faculty of Basic Medical Sciences, Abia State University, Uturu, Abia State, Nigeria.

e-mail: azibsmil32@yahoo.com 


\section{References}

1. Stedman TL. Stedman's Medical Dictionary, 27th ed. Baltimore: Lippincott Williams and Wilkins; 2000. p.95

2. Deopa D, Thakkar HK, Prakash C, Niranjan R, Barua MP. Anthropometric measurements of externalear of medical students in Uttarakhand region. J Anat Soc India. 2013; 62:79-83.

doi: 10.1016/S0003-2778(13)80018-4

3. Sharma N. Anthropometric measurement and cross-sectional surveying of ear pinna characteristics in Northern India. J Exp Clin Anat. 2016;5:02-6.

doi: 10.4103/1596-2393.200914

4. Ekanem AU, Garba SH, Musa TS, Dare ND. Anthropometric study of the pinna (Auricle) among adult Nigerians resident in Maiduguri metropolis. J Med Sci. 2010; 10(6): 176-80.

doi: 10.3923/jms.2010.176.180

5. Moore KL, Dalley AF. Clinical Oriented Anatomy, 5th ed. Lippincott Williams and Wilkins; 2006. p. 1022-1033.

6. Sinnatamby CS. Last's Anatomy, Regional and Applied, 10th ed. Churchill Livingstone, New York; 2000. p.406.

7. Standring S, Berkovitz BKB, Hackney CM. Development of ear. In: Gray's Anatomy. Anatomical Basis of Clinical Practice, 39th ed. (Standring S, Ellis $\mathrm{H}$, Healy JC, Johanson D, Williams A, eds). Elsevier Churchill Livingstone, London; 2005. p.680.

8. Azaria R, Adler N, Silfen R, Regev D, Hauben DJ. Morphometry of the adult human earlobe: A study of 547 subjects and clinical application. Plast Reconstr Surg. 2003; 111 (7): 2398402.

doi: 10.1097/01.PRS.0000060995.99380.DE

9. Sharma A, Sidhu NK, Sharma MK, Kapoor K, Singh B. Morphometric study of ear lobule in Northwest Indian male subjects. Anat Sci Int. 2007;82:98-104.

doi: 10.1097/01.PRS.0000060995.99380.DE

10. Ahmed SJ, Yaas NK. Study for Genetic Relation between the Attached Ear Lobes and Hairy Ears in a Selective Iraqi Sample. International Journal of Medical and Clinical Research. 2013; 4(2):261-262.

doi: 10.9735/0976-5530.4.2.261-262

11. Ordu KS, Didia BC, Egbunefu N. Inheritance Pattern of Earlobe Attachment amongst Nigerians. Greener Journal of Human Physiology and Anatomy. 2014;2(1):1-7

doi: 10.15580/GJHPA.2014.1.012214054

12. Verma P, Sandhu HK, Verma KG, Goyal S, Sudan M, Ladgotra, A. Morphological Variations and Biometrics of Ear: An Aid to Personal Identification. Journal of Clinical and Diagnostic Research. 2016; 10(5):138-142.

doi: $10.7860 / J C D R / 2016 / 18265.7876$

13. Mumin A, Olabu B, Ongeti K, Saidi H. Ethnic differences in the morphology of the pinna. Anatomy Journal of Africa. 2018;7(1):1097-102.

14. Kollali R. Earlobe Morphology; A simple classification of normal earlobes. Journal of Plastic Reconstructive and Aesthetic Surgery. 2009; 62:277280.

doi: $10.1016 / j . b j p s .2008 .01 .046$
15. Munir S, Sadeeqa A, Nergis B, Tariq N, Sajjad N. Assessment of Morphogenetic Inherited Traits; Earlobe Attachment, Bent Little Finger and Hitchhiker's Thumb in Quetta, Pakistan. World Journal of Zoology. 2015;10 (4): 252-255.

16. McDonald JH. Myths of Human Denetics, Delaware University, Sparky House Publishing; 2011. p. 10-16.

http://udel.edu/ mcdonald/mythearlobe-html. 17. Eboh D. Morphological changes of the human pinna in relation to age and gender of Urhobo people in Southern Nigeria. J Cli Exp Anat. 2013; 12:68-74. doi: 10.4103/1596-2393.127964

18. Wang B, Dong Y, Zhao Y, Shizhu Bai S, Wu G. Computed tomography measurement of the auricle in Han population of north China. J Plast Reconstr Aesthetic Surgery. 2011;64 (1): 3440.

doi: 10.1016/j.bjps.2010.03.053

19. Brucker MJ, Patel J, Sullivan PK. A morphometric study of the external ear: Age and sex related differences. Plast Reconstr Surg. 2003;112 (2): 64752.

doi: 10.1097/01.PRS.0000070979.20679.1F

20. Alexander KS, Stott DJ, Sivakumar B. A morphology study of the human ear. Journal of Plastic Reconstructive and Aesthetic Surgery. 2011; 64:41-47.

doi: 10.1016/j.bjps.2010.04.005

21. Ferrario VF, Sforza C, Ciusa V, Serrao G, Tartaglia GM. Morphometry of the normal human ear: A cross sectional study from adolescence to mid adulthood. J Craniofac Genet Dev Biol. 1999; 19 (4): 226-33.

22. Bozkir MG, Karakas P, Yavuz M, Dere F. Morphometry of the external ear in our adult population. Aesth Plast Surg. 2006;30 (1): 815.

doi: 10.1007/s00266-005-6095-1

23. Kalcioglu MT, Miman MC, Toplu Y, Yakinci C, Ozturan O. Anthropometric growth study of normal human auricle. Int J Pediatr Otorhinolaryngol. 2003; 67 (11): 116977.

doi: 10.1016/S0165-5876(03)00221-0

24. Barut C, Aktunc E. Anthropometric measurements of the external ear in a group of Turkish primary school students. Aesthet Plast Surg. 2006; 30 (2): 2559 e.

doi: 10.1007/s00266-005-0182-1

25. Sforza C, Ferrario VF. Soft tissue facial anthropometry in three dimensions: From anatomical landmarks to digital morphology in research, clinics and forensic anthropology.J Anthropol Sci. 2006; 84: 97-124.

26. Agnihotri G., Singh D. Craniofacial anthropometry in newborns and infants. Iran J Pediatr. 2007; 17 (4): 3328.

27. Purkait R, Singh P. Anthropometry of the normal human auricle: A study of adult Indian men. Aesthetic Plast Surg. 2007; 31 (4): 3719.

doi: $10.1007 / \mathrm{s} 00266-006-0231-4$

28. Ito I, Imada M, Ikeda M, Sueno K, Arikuni T, Kida A, et al. A morphological study of age changes in adult human auricular cartilage with special emphasis on elastic fibers. Laryngoscope 2001;111:881-6.

doi: 10.1097/00005537-200105000-00023 
29. Meijerman L, Van der Lugt C, Maat GJ. Crosssectional anthropometric study of the external ear. J Forensic Sci. 2007;52:286-93.

doi: 10.1111/j.1556-4029.2006.00376.x

30. Shah A, Fareed M, Hussain M, Afzal M. Phylogenetic relationships of muslim populations of Manipur based on morphogenetic markers. Physical Anthropology. 2012;8:463-480.

31. Kim KE, Song WJ, Kim DK. Reevaluation of the earlobe types in Koreans. Pubmed.2018; 69(6): 377380.

doi: $10.1016 / j . j c h b .2018 .10 .003$
32. Nwaopara AO, Anibeze CIP, Akpuaka FC, Agbotaen OF. Morphogenetic Traits combination pattern amongst the population of Ekpoma, Nigeria: Focus on Tongue Rolling, Ear lobe attachment, blood groups and genotypes. African Journal of Biotechnology. 2008;7:3593-3598.

33. Singh J, Sengupta S. Some Morphogenetic and behavioural traits among the Assamese Sikhs. Anthropologist. 2004;6(4):253-255.

doi: $10.1080 / 09720073.2004 .11890862$

Received 03 April 2019; revised 24 April 2019; accepted 15 May 2019.

This is an open access article distributed under the Creative Commons Attribution License, which permits unrestricted use, distribution, and reproduction in any medium, provided the original work is properly cited. 